\title{
FACTORS OF THE SPATIAL DEVELOPMENT OF RETAILERS IN THE LVIV REGION
}

\author{
Viktoria Klapchuk \\ Ivan Franko National University of Lviv, Ukraine \\ vikkikiki@ukr.net
}

\begin{abstract}
As a result of the research of retailers in the Lviv region, we identified the main factors that have the greatest impact on the development of modern trade facilities. Namely, there are identified the following groups of factors: economic and geographical; demographic and resettlement; social; and others. One of the most important indicators among the economic and geographical factors is the purchasing power of the population, which depends on its level of income, which allows you to spend more or less resources on the purchase of products. It has been established that the impact of income and expenditure on the population affects the placement of the retailers. It was revealed the interdependence between the number of population and the development of retailers. The population of the Lviv region is the largest among other regions of the Western region, and therefore the largest number of consumers is concentrated here. The largest city in this region is Lviv, and it concentrates the largest number of trading networks. Such cities as Drohobych and Chervonograd stand out among the cities of oblast significance, and among the districts the leaders in retail development are Yavoriv, Zhovkiv and Pustomyty. We also analysed the relationship between population density and the share of retail networks in regions and cities of oblast significance. The indicators of the population density in most cases coincide with the indicators of the share of retail chains. From the social factors the most characteristic for the Lviv region, is "patriotic consumption". Among other important factors we identify the availability of food markets, geographic location, etc. The availability of food markets partially reduces the number of consumers in modern trade facilities. The close geographical location of several areas to the EU border affects the development of retails.
\end{abstract}

Key words: retailers, economic-geographic factors, demographic and resettlement factors, social factors, consumerism, "patriotic consumption".

DOI: https://doi.org/10.17721/2413-7154/2017.78.26-34

UDC: $911.3: 339.378 .2(477.83)$

\section{ЧИННИКИ ПРОСТОРОВОГО РОЗВИТКУ ТОРГОВЕЛЬНИХ МЕРЕЖ У ЛЬВІВСЬКІЙ ОБЛАСТІ}

\author{
Вікторія КЛАПЧУК \\ Львівський національний університет імені Івана Франка, Україна \\ vikkikiki@ukr.net
}

\begin{abstract}
Анотація: У результаті дослідження торговельних мереж Львівської області, визначено основні чинники, які мають найбільший вплив на розвиток сучасних закладів сфери торгівлі. А саме виділено такі групи чинників: економікогеографічні; демографічні та розселенські; соціальні та інші. Одним із найважливіших показників економіко-географічних чинників $\epsilon$ купівельна спроможність населення, яка залежить від рівня його доходів, що дозволяє витрачати більше чи менше ресурсів на купівлю продукції. Встановлено, що вплив доходів і витрат населення впливає на розміщення торговельної мережі. Виявлено взаємозалежність між кількістю населення та розвитком торговельних мереж. Так, кількість населення Львівської області $\epsilon$ найбільшою серед інших областей Західного регіону, а тому тут зосереджена найбільша кількість споживачів. Найбільше місто у даному регіоні - Львів, тут зосереджено найбільше торгівельних мереж. Серед міст обласного значення вирізняються міста Дрогобич і Червоноград, а по районах першість мають Яворівський, Жовківський і Пустомитівський. Також проаналізовано залежність між щільністю населення та часткою торговельних мереж у районах та містах обласного значення. Показники щільності населення у більшості співпадають із показниками частки торговельних мереж. Для Львівської області серед соціальних чинників найбільш характерним $\epsilon$ «патріотичне споживання». Серед інших важливих чинників виділено показники наявності продовольчих ринків, географічне положення та ін. Наявність продовольчих ринків частково зменшує кількість споживачів у сучасних закладах торгівлі. Географічне положення декількох районів до країн $Є С$ впливає на розвиток торговельних мереж.

Ключові слова: торговельна мережа, економіко-географічні чинники, демографічні та розселенські чинники, соціальні чинники, консюмеризм, «патріотичне споживання».
\end{abstract}

DOI: https://doi.org/10.17721/2413-7154/2017.78.26-34

UDC: 911.3:339.378.2(477.83)

(C) В. Клапчук 
Iз проголошенням незалежності України вивчення торговельної сфери стало одним із пріоритетних питань, адже глобалізаційні процеси почали проявлятись у започаткуванні таких сучасних закладів торгівлі як гіпермаркети, супермаркети, мінімаркети та ін. Саме тому визначення чинників, що сприяють розвитку сучасних закладів торгівлі у Львівській області, дасть змогу виокремити закономірності їх поширення.

Вітчизняними дослідниками у цій сфері $\epsilon$ В. В. Апопій, О. О. Бакунов, Л. В. Балабанова, I. О. Бланк, Н. О. Голошубова, О. О. Кавун, Л. О. Лігоненко, А. А. Мазаракі, А. А. Садеков, Л. В. Фролова, В. І. Ящук та ін.

Н.О. Голошубова серед різноманіття факторів впливу на розвиток торгівлі виділяе наступні: соціально-економічні, демографічні, географічні, містобудівні, транспортні, організаційнотехнологічні, управлінські та фінансові [3]. Представники київської наукової школи під керівництвом А. А. Мазаракі поділяють фактори розвитку торгівлі на три групи: 1) загальні фактори, що діють в усіх галузях; 2) загальні фактори для всіх господарюючих суб'єктів на мікрорівні; 3) фактори господарської діяльності торговельних підприємств [5]. Доволі розповсюдженим в економічній науці $\epsilon$ розподіл факторів впливу на внутрішні та зовнішні за належністю до середовища $[1 ; 8 ; 9]$.

Львівська область за показником кількості наявних торговельних мереж (12) та сучасних закладів торгівлі (174) займає лідируючі позиції у Західному регіоні України. На початок 2015 p. у Львівській області проводять свою діяльність 12 торговельних мереж, зокрема, це «Арсен», «Ашан», «Барвінок», «Близенько», «Вопак», «Колібріс», «Наш Край», «Рукавичка», «Степ», «Сільпо», «Фуршет», «МЕТРО» (рис. 1). У Львівській області представлені всі види торговельних мереж. Найбільшу частку закладів що розташовані у Львівській області становлять заклади торговельної мережі «Рукавичка» - 43,7\%. Торговельні мережі «Барвінок» та «Наш Край» мають, відповідно, 18,6\% та 11\%. «Сільпо» та «Вопак», відповідно, 6,9\% та 6,4\%. Частка інших торговельних мереж дещо перевищує 4\%. Така ситуація свідчить про те, що майже половину ринку Львівської області контролює торговельна мережа локального типу «Рукавичка». Інші торговельні мережі не контролюють і 25\% ринку. У Львові, як найбільшому місті області функціонують 9 торговельних мереж. Також досить велике різноманіття торговельних мереж представлено у м. Стрий (7 торговельних мереж). У Червонограді, як одному із найбільш густонаселених міст Львівської області зосереджено всього 3 торговельні мережі. Окрім того, торговельні мережі Львівської області представлені лише у декількох населених пунктах сільської місцевості. Такі показники спричинені чотирма основними групами чинників, які сприяють розвитку торговельних мереж: економіко-географічними;

демографічними та розселенськими; соціальними та іншими чинниками.

Під економіко-географічним чинником, в основному, розуміють вплив доходів і витрат населення на розміщення торговельної мережі, a також економіко-географічне положення області. Адже основним чинником успішного функціонування торговельної мережі $є$ купівельна спроможність населення, яка залежить від рівня його доходів, що дозволяє витрачати більше чи менше ресурсів на купівлю тієї чи іншої продукції.

У Львівській області протягом останніх років (рис. 2), незважаючи на щорічне збільшення наявного доходу на одну особу, спостерігається менша купівельна спроможність населення внаслідок знецінення національної валюти.

У містах обласного значення Львівської області простежується чітка взаємозалежність між показниками роздрібного товарообороту на одну особутасередньомісячноюномінальноюзаробітною платою працівників (рис. 3; рис. 4). Встановлено, що завдяки підвищенню купівельної спроможності населення відбувається пропорційне зростання заробітної плати й товарообороту підприємств на одну особу. Не відбулося пропорційного зростання у таких містах, як Львів, Самбір та Червоноград.

Враховуючи соціальну спрямованість торгівлі, яка направлена на забезпечення товарами та послугами суспільство, можна із впевненістю сказати, що демографічний чинник має значний вплив як на побудову i розвиток торговельних мереж, так i на реалізацію їх економічної спрямованості. Тобто, торговельна мережа буде найбільше розвиватися там, де $\epsilon$ купівельноспроможне населення, де $\epsilon$ значна кількість населення, i звичайно ж, де $\epsilon$ робоча сила, необхідна для обслуговування цієї торговельної мережі. Певна взаємозалежність спостерігається між демографічними показниками (загальна чисельність та щільність населення) і показниками, що характеризують розвиток торговельних мереж (табл. 1).

Простежується взаємозалежність між кількістю населення та розвитком торговельних мереж. Таку ситуацію можна пояснити тим, що кількість населення Львівської області є найбільшою серед інших областей Західного регіону, а тому тут зосереджена найбільша кількість споживачів. Серед міст обласного значення вирізняються міста Дрогобич і Червоноград, а серед районів першість мають Яворівський, Жовківський і Пустомитівський. Щодо такого показника як кількість населення, що припадає на 1 торговельний заклад, то він не покаже правдивої картини забезпеченості населення торговельними мережами. Адже тут повинна враховуватись площа торговельного закладу, його тип, асортимент товарів та ін. фактори. Та все ж уявлення про загальну ситуацію забезпеченості можна побачити з табл. 1, звідки бачимо, що у Львові на 10,5 тис. осіб припадає один 


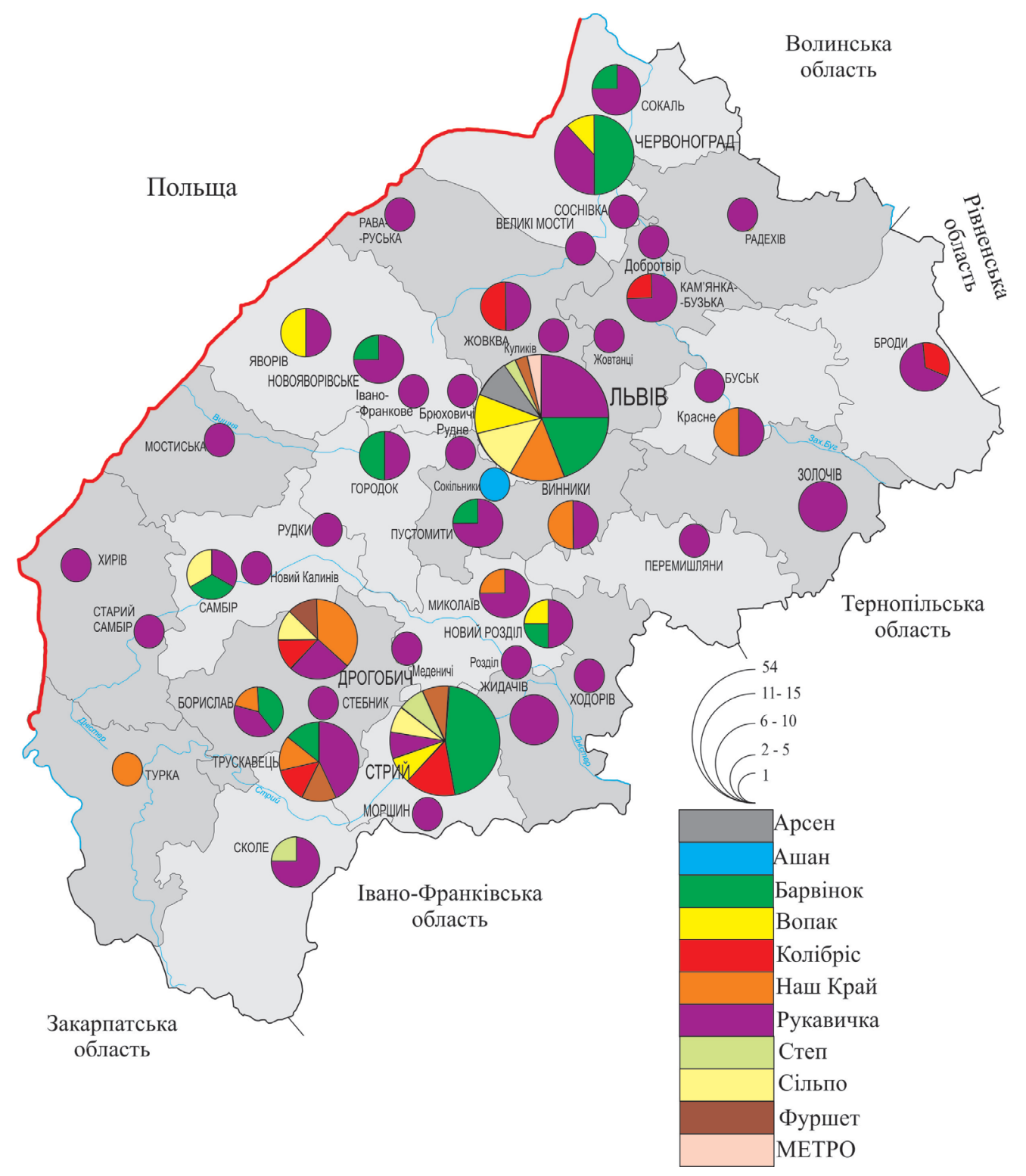

Рис. 1. Торговельні мережі Львівської області, 2015 р.

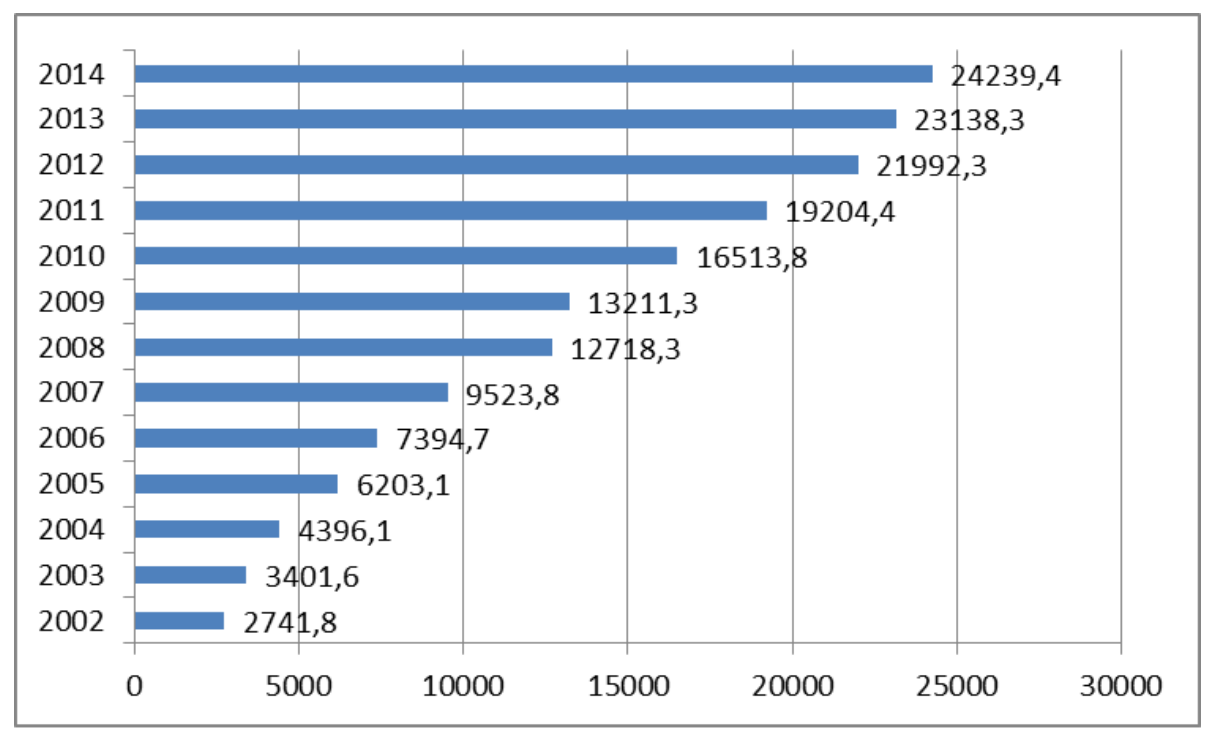

Рис. 2. Наявний дохід на одну особу з 2002-2014 рр. у Львівській області, грн. Джерело: [2] 
заклад торгівлі сучасного типу; в інших містах цей показник коливається від 4 до 11 тис.осіб. В районах значення цього показника $€$ значно вищими і коливаються вже від 12 тис. до 74,6 в Дрогобицькому районі.

Розселення характеризується відмінностями у щільності населення, сукупністю населених пунктів (міст, селищ, сіл) різної величини та співвідношенням чисельності міських і сільських жителів. Розселенський чинник $€$ одним iз основних в розміщенні торговельних мереж. На сьогоднішньому етапі розвитку більшість закладів торгівлі розташовані в містах та селищах міського типу із високою щільністю населення. Цілком інша ситуація в селах, де такі заклади як супермаркети чи гіпермаркети практично відсутні. Там населення забезпечує себе більшістю продуктів харчування самостійно або здійснює покупки у таких закладах торгівлі як «магазин біля дому». 3 рис. 5 та 6 бачимо, що спостерігається взаємозалежність між щільністю населення та часткою торговельних мереж у районах та містах обласного значення.
Показники щільності населення у більшості співпадають із показниками частки торговельних мереж. Перш за все, це зафіксовано у містах області. Центральні райони характеризуються високою часткою торговельних мереж, адже щільність населення серед районів тут найвища (рис. 5). Особлива ситуація спостерігається у Дрогобицькому районі, де частка торговельних мереж низька (рис. 6), що спричинено високою часткою торговельних мереж у містах, розташованих на території району, які забезпечують населення у торговельних потребах. Подібна ситуація спостерігається й у Стрийському районі. Щодо гірських районів, то тут зафіксовано низьку частку торговельних мереж і низьку щільність населення. Адже така місцевість потребує більш щільного розташування торговельних закладів, але вже 3 невеликою площею. Саме це дозволить задовільнити населення цих регіонів у торговельних потребах.

Сучасні заклади торгівлі розміщуються в містах різного класу, найбільше їх зосереджено у великих містах. Саме тому за наявності всіх передумов для

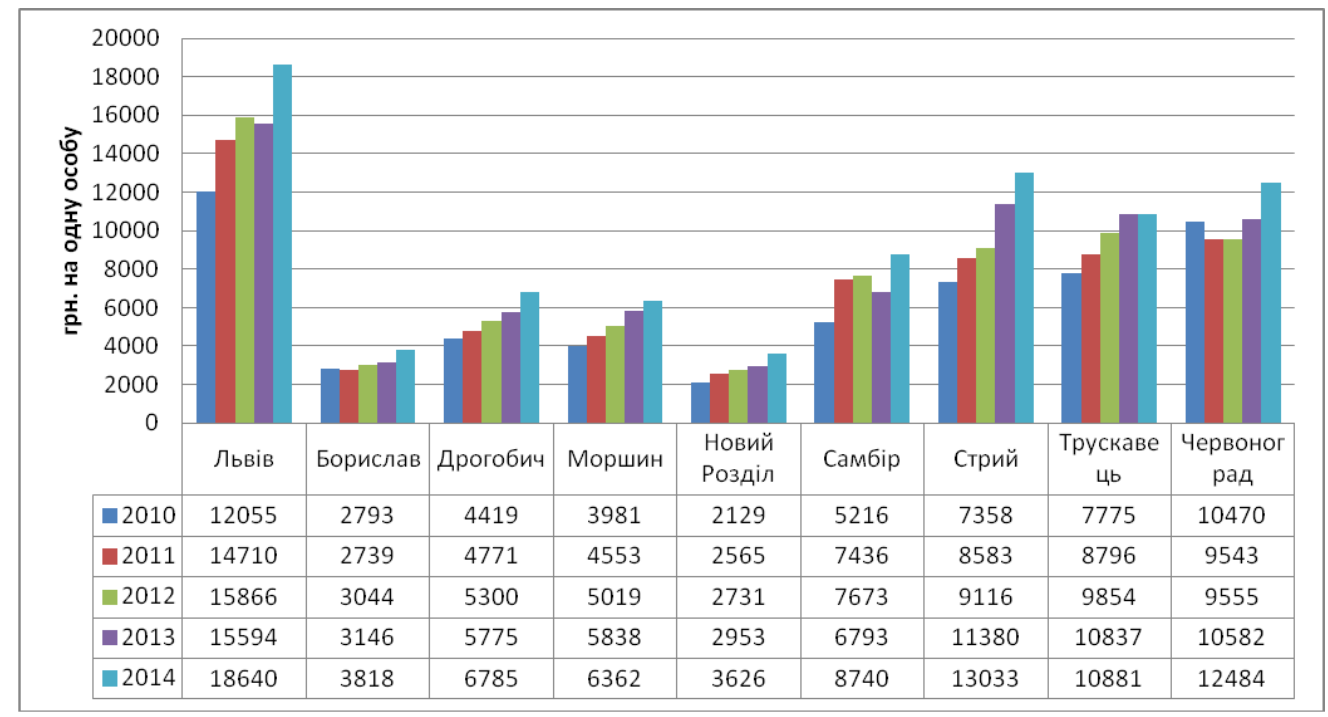

Рис. 3. Роздрібний товарооборот підприємств на одну особу. Джерело: [2]

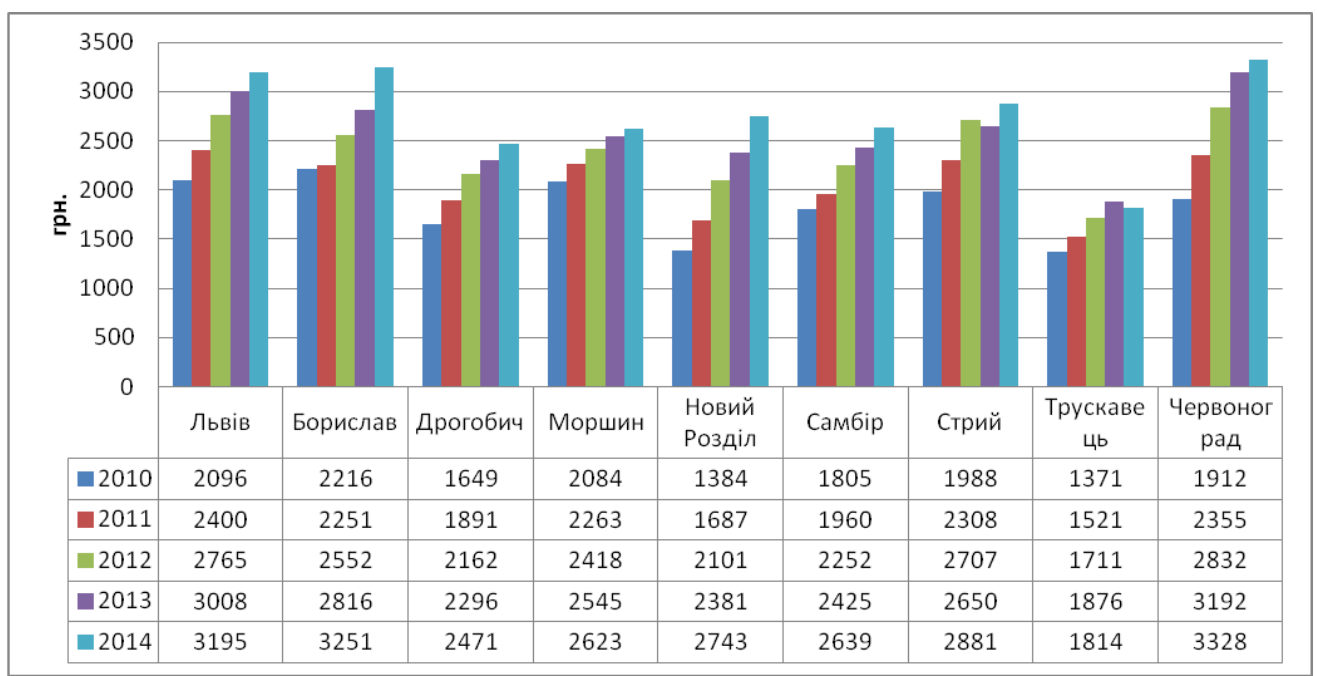

Рис. 4. Середномісячна номінальна заробітня плата працівників. Джерело: [2] 
переведення населених пунктів у вищі категорії, це буде мати позитивний вплив не тільки на розвиток торгівлі, а й на розвиток сфери послуг в конкретному населеному пункті загалом. Саме ця закономірність (розміщення закладів торгівлі у міських поселеннях) найкраще відображена в Східному регіоні України, де значно переважають такі заклади торгівлі як супермаркети та гіпермаркети.

Що стосується Львівської області, то великі міста тут відсутні, за винятком м. Львова. Середніх міст - три (Дрогобич, Стрий та Червоноград), малих - 40. Дещо менша кількість селищ міського типу - 35 (табл. 2).

Соціальна роль торгівлі полягає в тому, що вона, будучи найважливішою галуззю соціальної інфраструктури, сприяє фізичному i духовному розвитку особистості, забезпечує населення в споживчих товарах. Раціональне розміщення торговельної мережі, широкий асортимент товарів і послуг, які надаються населенню - один 3 найважливіших чинників у скороченні витрат позаробочого часу на пошуки і купівлю необхідних товарів, підвищення життєвого рівня кожної людини окремо і населення - в цілому. Завдяки розгалуженій мережі оптової і роздрібної торгівлі споживчі товари, вироблені різними підприємствами, які розташовані в різних районах і навіть країнах, стають доступними покупцеві в такому місці і в такий час, як це вигідно для покупця. Тобто, можна говорити, що торгівля сприяє вирівнюванню соціальних умов життя різних територіальних груп населення, до певної міри зближує рівні торгівельного обслуговування у великих і малих містах, сільській місцевості, хоча тут варто зауважити, що ці відмінності існуватимуть завжди [7].

Важливим поняттям $є$ демонстративне споживання, що $є$ водночас показником соціального статусу та культурного рівня розвитку суспільства Оскільки споживання здатне впливати як фактор, що констатує статус, то воно саме стає стимулом розвитку. Якщо нижчі верстви починають одержувати товари і послуги, типові для споживання вищих верств, тоді й ті намагаються переміститися на рівень більш високого способу споживання. Результатом (особливо на прикладі «модного» споживання) стає повсюдна гонитва за новинками моди, що викликає додаткові труднощі для фірм-виробників, завданням яких є задоволення попиту, який відповідає соціальному статусу різних верств населення [7].

Дефіцит товарів за часів Радянського Союзу спричинив появу такого явища, як консюмеризм. Консюмеризм - сукупність суспільних відносин, заснованих на принципі індивідуального споживання; характеризується масовим споживанням матеріальних благ i формуванням відповідної системи цінностей і установок. Масове споживання, яке виходить далеко за межі потреб для існування (виживання) людини, $є$ однією з рис сучасного суспільства [6].

До інших чинників можна віднести: географічне положення області, чи окремого населеного пункту, особливості забудови населених пунктів, інвестиційну привабливість області, розвиток сільського господарства в області, розвиток підприємництва, психологічні особливості населення регіону та розвиток ринків. Саме на розміщення супермаркетів в конкретному місці впливає і архітектурний стиль. Має вплив і такий чинник як ментальність населення, стереотипи та інші чинники, які мають не менш помітний вплив. Особливо цей чинник впливає на розвиток торгівлі в останні роки, коли відчуття патріотизму впливають на торгівлю і спричинили появу такого явища як «патріотичне споживання».

Щодо географічного положення, то тут основний вплив є у сусідському положенні держав, зокрема СС та інших держав. Сусідське положення Львівської області щодо розвиненішої країни ЄС сприяє відсутності національних торговельних мереж або малій кількості закладів торгівлі у прикордонних населених пунктах. Хоча після 2009 р. ситуація дещо змінилась, оскільки зниження курсу національної валюти призвело до дорожчання імпортної продукції. Тому в прикордонних районах почали з'являтися заклади різних торговельних мереж. Вплив сусідньої держави на торговельну ситуацію $\epsilon$ значним адже більшість населення здійснює покупки за межами України, особливо те населення, яке має дозвіл на спрощений прикордонний рух у 30-кілометровій зоні з обох боків кордону. Завдяки цьому жителі, які живуть у прикордонній зоні України можуть регулярно перетинати кордон без візи для того щоб відвідати сусідню державу, у тому числі, і з торговельною метою. Криза 2014-2015 pр. i обвал гривні суттєво знизили рентабельність покупок за кордоном і відкривають можливості для національних торговельних мереж.

Важливим $є$ й те, що не зникла довіра українського населення до стихійних та офіційних ринків, адже на території України їх є досить багато. 3 рис. 7, видно, що хоча кількість ринків 3 кожним роком зменшується, все ж їх кількість вказує на те, що населення робить свої покупки саме там, або ж проживає за рахунок роботи на таких ринках, і повне їх знищення буде мати дуже двосторонній вплив для економіки та населення України.

Під час вибору конкретного місця розташування торговельного закладу будь якого типу існує декілька факторів, які необхідно врахувати:

- Рельєф місцевості (аналіз рельєфу місцевості, де планується відкриття торговельного закладу допоможе визначитись із типом торговельної точки, тобто, важливо врахувати гірська місцевість чи рівнинна, адже на гірській місцевості доцільніше будувати «магазини біля дому» - це полегшує доступність населення до закладів торгівлі);

- Конкурентна ситуація (аналіз конкурентної ситуації торговельної зони, допоможе уникнути наслідків конкуренції із більш відомими торговельними мережами);

- Транспортне сполучення у вибраній місцевості та наявність зупинок громадського транспорту або ж місця для організації парковок (врахування цього 
Наявне населення, щільність населення та кількість закладів торговельних мереж Львівської області

\begin{tabular}{|c|c|c|c|c|}
\hline $\begin{array}{l}\text { Адміністративно- } \\
\text { територіальні } \\
\text { утворення }\end{array}$ & $\begin{array}{c}\text { Наявне } \\
\text { населення, тис. } \\
\text { осіб }\end{array}$ & $\begin{array}{l}\text { Щільність, } \\
\text { осіб/1 км² }\end{array}$ & $\begin{array}{c}\text { Кількість } \\
\text { закладів торг. } \\
\text { мереж }\end{array}$ & $\begin{array}{c}\text { Кількість населення } \\
\text { що припадає на } 1 \text { торг. } \\
\text { заклад, тис. осіб }\end{array}$ \\
\hline \multicolumn{5}{|c|}{ Міста обласного значення } \\
\hline Львів & 759,1 & 4439,2 & 72 & 10,5 \\
\hline Борислав & 36,9 & 971,1 & 5 & 7,4 \\
\hline Дрогобич & 97,7 & 2171,1 & 9 & 10,9 \\
\hline Моршин & 6,0 & 3000 & 1 & 6,0 \\
\hline Новий Розділ & 28,8 & 1309,1 & 4 & 7,2 \\
\hline Самбір & 35,1 & 2340 & 3 & 11,7 \\
\hline Стрий & 59,6 & 3505,9 & 13 & 4,6 \\
\hline Трускавець & 29,3 & 3662,5 & 7 & 4,2 \\
\hline Червоноград & 82,1 & 3909,5 & 9 & 9,1 \\
\hline \multicolumn{5}{|c|}{ Райони } \\
\hline Бродівський & 59,5 & 51,2 & 3 & 19,8 \\
\hline Буський & 46,3 & 54,5 & 3 & 15,4 \\
\hline Городоцький & 69,1 & 95,2 & 2 & 34,6 \\
\hline Дрогобицький & 74,6 & 61,9 & 1 & 74,6 \\
\hline Жидачівський & 69,1 & 69,4 & 3 & 23,0 \\
\hline Жовківський & 110 & 85 & 4 & 27,5 \\
\hline Золочівський & & 63,4 & 2 & 34,8 \\
\hline Кам'янка-Бузький & 57,3 & 66 & 5 & 11,5 \\
\hline Миколаївський & 63,2 & 93,6 & 4 & 15,8 \\
\hline Мостиський & 57,3 & 67,8 & 1 & 57,3 \\
\hline Перемишлянський & 39,2 & 42,7 & 1 & 39,2 \\
\hline Пустомитівський & 115,3 & 121,9 & 4 & 28,8 \\
\hline Радехівський & 48,0 & 42 & 1 & 48,0 \\
\hline Самбірський & 68,7 & 73,6 & 2 & 34,4 \\
\hline Сколівський & 47,8 & 32,5 & 3 & 15,9 \\
\hline Сокальський & 93,1 & 59,3 & 4 & 23,3 \\
\hline Старосамбірський & 78,2 & 62,8 & 2 & 39,1 \\
\hline Стрийський & 62,0 & 76,7 & - & - \\
\hline Турківський & 50,1 & 42 & 1 & 50,1 \\
\hline Яворівський & 124,9 & 80,9 & 7 & 17,8 \\
\hline
\end{tabular}

Джерело: [2]

Таблиия 2

Класи міст Львівської області за людністю

\begin{tabular}{|c|c|c|c|c|c|}
\hline \multirow[b]{2}{*}{$\begin{array}{l}\text { Обл. } \\
\text { (к-сть міст) }\end{array}$} & \multicolumn{4}{|c|}{ Міста } & \multirow[b]{2}{*}{$\begin{array}{c}\text { Селища } \\
\text { міського типу }\end{array}$} \\
\hline & $\begin{array}{c}\text { Великі } \\
\text { (100-500тис.) }\end{array}$ & $\begin{array}{c}\text { Середні } \\
(50-100 \text { тис.) }\end{array}$ & $\begin{array}{c}\text { Малі } \\
\text { (до } 50 \text { тис.) }\end{array}$ & $\begin{array}{c}\text { Спеціального } \\
\text { статусу }\end{array}$ & \\
\hline Львівська (44) & 0 & 3 & 40 & 9 & 35 \\
\hline
\end{tabular}

Джерело: [2] 

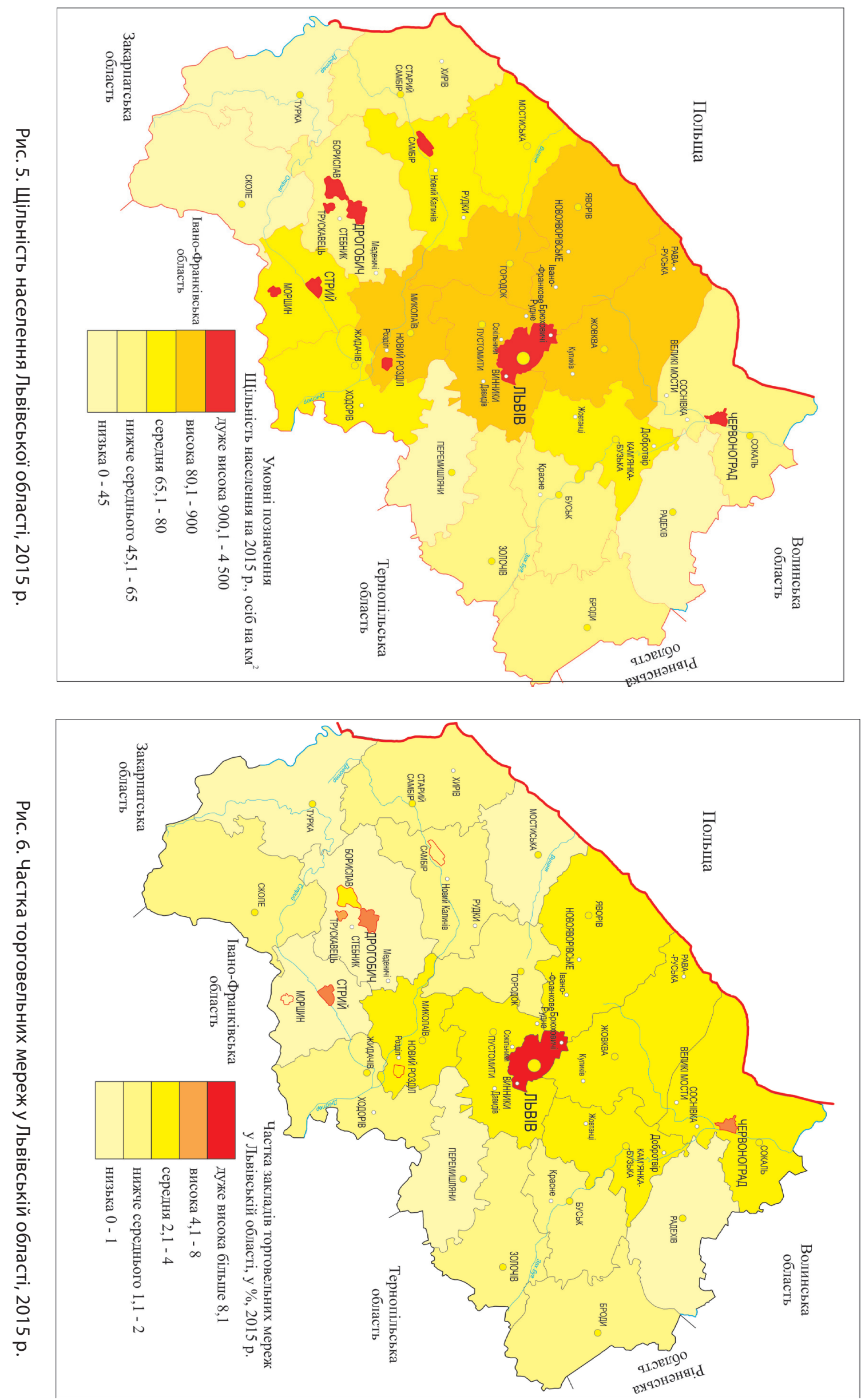


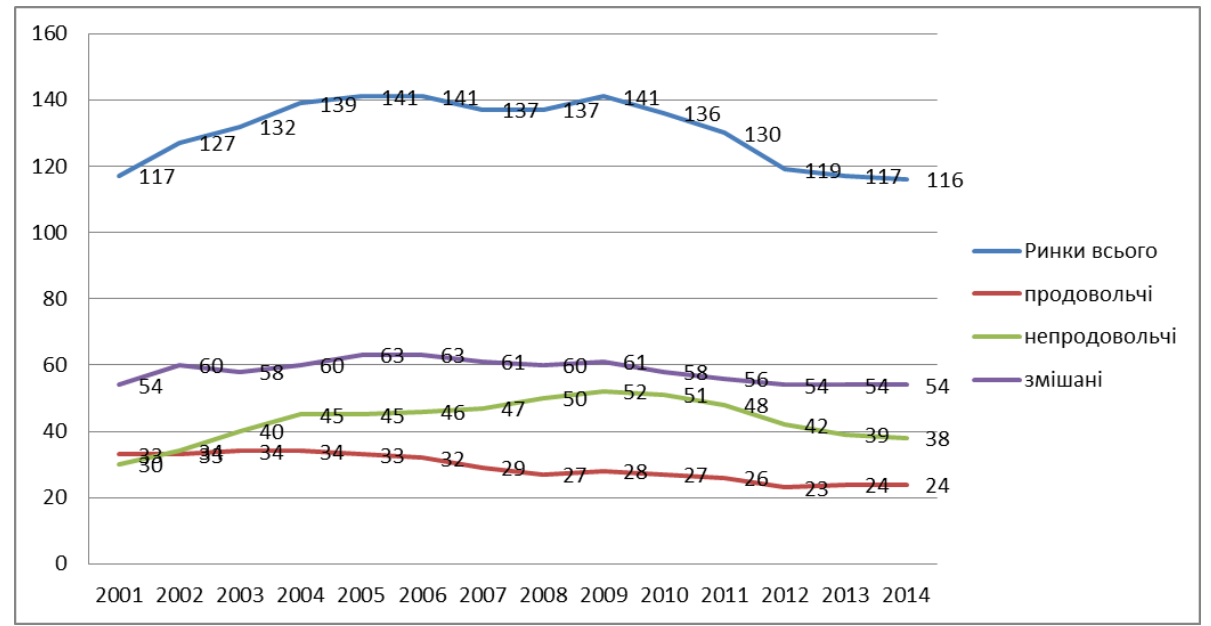

Рис. 7. Динаміка кількості ринків Львівської області 2001-2014 рр. Джерело: [9]

чинника дає можливість дістатись до торговельної мережі із будь якого куточка міста);

- Архітектурний стиль вибраної місцевості та наявність вільних від забудови земель (чинник, що є дуже важливим, адже від нього залежить, чи буде торговельний заклад окремою будівлею);

- Наявність торговельних комплексів поруч, із відомими якірними орендаторами, які зацікавлять більшу частку покупців, тим самим зменшать доходи відкритої торговельної мережі (якірний орендар - великий, як правило мережний, оператор роздрібної торгівлі з відомим брендом, розташований на території ТЦ на правах орендаря чи власника займаної площі i приваблює до ТЦ основні потоки покупців [4]. Також наявність торговельного комплексу поблизу відкритого торговельного закладу буде сприяти його відвідуваності);

- Наявність ринків поблизу торговельної мережі (аналіз ринкової діяльності в межах функціонування торговельного закладу скоротить кількість споживачів торговельної мережі).

Висновки. Існують різні думки щодо виокремлення чинників, які впливають на розвиток та функціонування торговельних мереж. Серед багатьох науковців, що виділяють ці чинники, важливими є дослідження Н.О. Голошубової та А. А. Мазаракі.

У Львівській області проводять свою діяльність 12 торговельних мереж, зокрема, це «Арсен», «Ашан», «Барвінок», «Близенько», «Вопак», «Колібріс», «Наш Край», «Рукавичка», «Степ», «Сільпо», «Фуршет», «МЕТРО». Загальна кількість торговельних закладів усіх мереж становить 176 одиниць.

Виділено чотири основні групи чинників, які сприяють розвитку торговельних мереж: економіко-географічні;

демографічні розселенські; соціальні та інші чинники. Однією iз основних $є$ група економіко-географічних чинників. Купівельна спроможність населення, яка залежить від рівня його доходів показує найбільшу взаємозалежність населених пунктів та районів Львівської області між показниками що характеризують торговельну сферу.

Спостерігається взаємозалежність між кількістю населення та розвитком торговельних мереж. На сьогоднішньому етапі розвитку більшість закладів торгівлі розташовані в містах та селищах міського типу із високою щільністю населення. Цілком інша ситуація в селах, де такі заклади як супермаркети чи гіпермаркети практично відсутні.

Серед соціальних чинників найбільш важливим у Львівській області $\epsilon$ «патріотичне споживання», адже більшість торговельних мереж відзначають товари вироблені в Україні.

Інші важливі чинники, що впливають на розвиток торговельних мереж Львівської області: географічне положення області, чи окремого населеного пункту, особливості забудови населених пунктів, інвестиційну привабливість області, розвиток сільського господарства в області, розвиток підприємництва, психологічні особливості населення регіону та розвиток ринків.

Перед відкриттям торговельної мережі необхідно врахувати декілька факторів: рельєф місцевості, конкурентна ситуація, транспортне сполучення та наявність зупинок громадського транспорту, архітектурний стиль та наявність вільних від забудови земель, наявність торговельних комплексів, наявність ринків поблизу торговельної мережі.

\section{References:}

1. Bêlâêva M.V. Ekonomičnij mehanizm regulûvannâ pidpriêmnic'koï dîal'nostì v torgìvlì [Economic mechanism for the regulation of entrepreneurial activity in trade]: PhD Thesis. Kharkìv, 2010, 181 p. (In Ukrainian).

2. Main Statistical Office in Lviv region. Access mode: lv.ukrstat.gov.ua/ 
3. Golosubova N. O. Viznačal'nì faktori rozvitku rozdribnoï torgovel'noï merežì [Main factors of the retail development]. Visnik KNTEU, 2004, N. 4, pp. 18-26. (In Ukrainian).

4. Klasifikaciâ torgovih centrìv: êvropejs'kì standarti [Classification of shopping malls: European standards], Upravlenienedvižemost'û,2006. Access mode:http://www.dvoretsky.ru/modules/myarticles/article.php?storyid=188 (In Ukrainian).

5. Mazarakì A. A. Ekonomika torgovel'nogo pìdpriêmstva [Economy of a trading enterprise]. Kyiv, 1999, 800 p. (In Ukrainian).

6. Matvêêv S. O., Lâsota L. İ. Ekonomična sociologiâ [Economic Sociology]. Sumy, 2006, 184 p. (In Ukrainian).

7. Mìcenko N. G. Socìal'nì aspekti rozvitku rozdribnoï torgivlì v umovah transformacìjnih procesìv [Social aspects of retail development under the transformation processes]. Access mode: http://nltu.edu.ua/nv/ Archive/2007/17_3/177_Micenko_17_3.pdf(In Ukrainian).

8. Otenko I. P. Mehanizm upravleniâ potencialom predpriâtiâ [Management mechanism of enterprise potential: a scientific publication]. Kharkiv, 2003, 220 p. (In Russian).

10. Polâns'ka A. S., Oriŝin T. M. Doslidžennâ činnikiv zovnišn'ogo seredoviŝa âk neobhidna umova rozvitku pidpriêmstv $v$ sučasnih umovah [Investigation of the environmental factors as a necessary condition for the development of enterprises in modern conditions], Regional economy, 2010, N. 2 (56), pp. 39-47. (In Ukrainian).

11. Torgìvlâ L'vivs'koï oblastì. 2014 rik. Statističnij zbirnik [Statistical collection "Trade in Lviv region in 2014]. Lviv, 2014, 100 p. (In Ukrainian). 